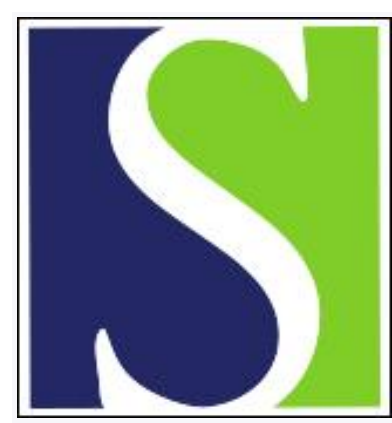

Scand J Work Environ Health 1990;16(3):163-168

https://doi.org/10.5271/sjweh. 1800

Issue date: 01 Jun 1990

Low birthweight, congenital malformations, and spontaneous abortions among dry-cleaning workers in Scandinavia.

by Olsen J, Hemminki K, Ahlborg G, Bjerkedal T, Kyyronen P, Taskinen $\mathrm{H}$, Lindbohm ML, Heinonen OP, Brandt L, Kolstad $\mathrm{H}$, et al.

Affiliation: Institute of Social Medicine, University of Aarhus, Denmark.

This article in PubMed: www.ncbi.nlm.nih.gov/pubmed/2143312

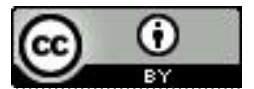




\title{
Low birthweight, congenital malformations, and spontaneous abortions among dry-cleaning workers in Scandinavia
}

\author{
by Jørn Olsen, MD, Kari Hemminki MD, Gunnar Ahlborg, MD, Tor Bjerkedal, MD, \\ Pentti Kyyrönen, Helena Taskinen, MD, Marja-Liisa Lindbohm, MSc, Olli P Heinonen, MD, \\ Lars Brandt, MD, Henrik Kolstad, MD, Bjørn A Halvorsen, MD, John Egenæs, MD
}

\begin{abstract}
OLSEN J, HEMMINKI K, AHLBORG G, BJERKEDAL T, KYYRÖNEN P, TASKINEN H, LINDBOHM M-L, HEINONEN OP, BRANDT L, KOLSTAD H, HALVORSEN BA, EGENAES J. Low birthweight, congenital malformations, and spontaneous abortions among dry-cleaning workers in Scandinavia. Scand $J$ Work Environ Health 1990;16:163-8. With a common study protocol, case-referent studies within cohorts were performed in Denmark, Norway, Sweden, and Finland to study reproductive hazards of women doing dry-cleaning work. Due to national differences not all of the studies could follow exactly the same procedures in data collection, but they were all based on the linkage of cohorts of dry-cleaning and laundry workers to national registers of births and reproductive failures. Summary measures from each study were combined without the data being pooled. The most significant finding was an increased risk of spontaneous abortion among the most exposed women in the Finnish data. This finding was only supported by the results of the other studies to a minor degree, and the combined odds ratio had confidence limits which included unity.
\end{abstract}

Key terms: combined analysis, dry cleaning, epidemiology, meta-analysis, reproductive failure, tetrachloroethylene.

In searching for causes of reproductive failures, epidemiologists have also taken an interest in the work environment, and the reasons are obvious. Increasing numbers of women are gainfully employed, and some of these women are exposed to physical and chemical agents which may influence reproductive capacity.

Women engaged in dry cleaning form such a group. Large amounts of chlorinated solvents - especially tetrachloroethylene - are used in dry-cleaning shops and plants. Tetrachloroethylene is mutagenic in several test systems and is associated with cancer in some animal tests. According to the International Agency for Research on Cancer (1) there is sufficient evidence of the carcinogenicity of tetrachloroethylene in animals, but for humans the evidence is inadequate.

The chemical has also been associated with reproductive failures in experimental animals such as rats, mice, and chickens $(2,3)$.

Very few studies on reproductive failures in humans have been published. In a Finnish study of chemical workers high proportions of spontaneous abortions

\footnotetext{
1 Institute of Social Medicine, University of Aarhus, Aarhus, Denmark.

2 Institute of Occupational Health, Helsinki, Finland.

3 Department of Occupational Medicine, Örebro, Sweden.

4 Department of Preventive Medicine, University of Oslo, Oslo, Norway.

s Public Health Institute, Helsinki, Finland.
}

Reprint requests to: Dr J Olsen, Institute of Social Medicine, University of Aarhus, Hoeghguldbergsgade 8, DK-8000 Aarhus C, Denmark. were found, and one-tenth of the study population was made up of dry-cleaning and laundry workers (4). Two other small studies indicated more frequent spontaneous abortions among women exposed to organic solvents in comparison with unexposed workers, but none of the differences reached statistical significance $(5,6)$.

\section{Subjects and methods}

According to a common Nordic study protocol all active laundries and dry-cleaning plants (in Denmark only dry-cleaning plants) were to be identified. From company records all the women having worked at the plants for at least one month during 1973-1983 were enrolled in a cohort, and their type of work and exposures at the plants were obtained.

Through the use of the personal identification numbers assigned to every resident of each of the Nordic countries, the collected data were linked with the data of the central medical birth registers and hospital registers. All pregnancy-related data in the analysis was taken from the registers.

In Sweden, Finland, and Norway a matched casereferent study was conducted within the cohort. In Denmark all the women in the cohort and every pregnancy that occurred in the study period were included in the analysis.

Data on exposure during pregnancy were collected with a standardized interview in Sweden and Denmark and with a postal questionnaire in Finland. In Norway exposure data were obtained from the employers. 
Women were defined as cases if they had given birth to a child with a birthweight of less than $1500 \mathrm{~g}$ (except in the Finnish study), a child with a congenital malformation (excluding certain minor malformations — codes 744.4, 745.10, 745.40, 747.70,752.10, 752.40, $755.02,755.03,755.6$, and 757.19 of the eighth revision of the International Classification of Diseases), or a child who died perinatally (Swedish and Norwegian study) or if they had had a pregnancy which ended as a spontaneous abortion (Swedish, Finnish, and Danish study). Matched referents were selected for each case with the mother's age ( \pm 2 years), year of pregnancy, and parity (except in the Finnish study) as matching criteria.

The identification of plants turned out to be very difficult, and several data sources had to be used, eg, official registers, telephone books, data from employers' associations, etc. Table 1 presents the estimated coverage and refusal rates of Sweden, Norway and Denmark. The data collection in the Finnish study followed a slightly different scheme, as has been described later.

In the Swedish study 7299 women who had worked for at least one month at one or more of the plants during 1973-1983 were identified. According to the linkage with the medical registers 2581 women had had a registered pregnancy sometime between 1974-1983, and 955 of them had worked at a laundry or at a drycleaning plant during at least part of the 12 months before delivery or the six months before spontaneous abortion. Out of this group 67 were cases according

Table 1. Estimated number of dry-cleaning plants and the refusal rates for Sweden, Norway, and Denmark.

\begin{tabular}{lcc}
\hline Country & $\begin{array}{c}\text { Identified } \\
\text { number } \\
\text { of plants }\end{array}$ & $\begin{array}{c}\text { Number of plants } \\
\text { which did not } \\
\text { participate }\end{array}$ \\
\hline Sweden & 1254 & 779 a \\
Norway & 345 & 58 \\
Denmark & 355 & 123 \\
\hline
\end{tabular}

a Includes also closed plants which were still registered at the time of the Swedish inquiry. to our definition. From the women with normal pregnancies two referents were matched to each case. Nine women could not be located (missing address), and $84 \%$ of those remaining responded to a questionnaire. Furthermore, if both referents or the case was missing from the matched set, the whole triplet was deleted from the analysis. One triplet was excluded since the time of the case pregnancy could not be established. The final study population is shown in table 2 . The malformations were of the larynx, the lip, the palate ( 2 children), and the tongue, and there was also one case of congenital stenosis of the pylorus. More-detailed information on the Swedish study is given in reference 7 .

In the Norwegian study 4100 women who had worked for at least one month at one or more of the plants during 1972-1984 were identified. Linkage with the birth register identified 1805 births, of which 455 belonged to women who had worked at a laundry or at a dry-cleaning plant during pregnancy. No data on spontaneous abortions were available in this study. Fourteen fulfilled the case definition (congenital malformations or low birthweight, ie, $<1500 \mathrm{~g}$ ), and these were matched to two referents according to criteria similar to that used in the Swedish study. The malformations were of the eye, the small intestine (atresia), the fingers (syndactylia), and the foot (talipes) and also Down syndrome.

All exposure data in this data set were obtained from the employers, since regulations prohibited direct contact with the case-referent group.

In the Danish study dry-cleaning establishments and laundries were organized and registered differently and only dry-cleaning plants were included. One thousand one hundred and sixty-four women had been employed for at least one month at the listed plants. By linkage with the birth register and the patient hospital register 185 pregnancies (14 spontaneous abortions) were identified in 1979-1984. All the women were asked to participate in a telephone interview, and 143 interviews were completed. Questions similar to those on life-style factors and exposure status in the Swedish study were asked. The interviewer had no knowledge

Table 2. Definition of the cases within the cohort

\begin{tabular}{|c|c|c|}
\hline Country & Diagnoses & Remarks \\
\hline Sweden & $\begin{array}{l}\text { Spontaneous abortions }(N=31) \text {, low birth- } \\
\text { weight }(N=5) \text {, malformations }(N=6) \text {, deaths } \\
(N=5)\end{array}$ & $\begin{array}{l}\text { Matched case-referent study, } 321: 2 \text { matched strata, } \\
151: 1 \text { matched strata, data available on life-style } \\
\text { factors }\end{array}$ \\
\hline Norway & Low birthweight $(\mathrm{N}=7)$, malformations $(\mathrm{N}=7)$ & $\begin{array}{l}\text { Matched case-referent study, } 141: 2 \text { matched strata, } \\
\text { no data available on life-style factors }\end{array}$ \\
\hline Denmark & $\begin{array}{l}\text { Spontaneous abortions }(N=10) \text {, low birth- } \\
\text { weight }(N=1) \text {, malformations }(N=1)\end{array}$ & $\begin{array}{l}\text { Analysis of total cohort, } 143 \text { pregnancies, data avail- } \\
\text { able on life-style factors }\end{array}$ \\
\hline Finland & $\begin{array}{l}\text { Spontaneous abortions }(N=118) \text {, malforma- } \\
\text { tions }(N=24)\end{array}$ & $\begin{array}{l}\text { Matched case-referent study; abortion study: } 191: 1 \\
\text { matched strata, } 521: 2 \text { matched strata, } 471: 3 \text { matched } \\
\text { strata; malformation study: } 71: 3 \text { matched strata, } \\
131: 4 \text { matched strata, } 51: 5 \text { matched strata, data avail- } \\
\text { able on life style-factors }\end{array}$ \\
\hline
\end{tabular}


of the pregnancy outcome. Only one child was diagnosed with a congenital malformation (closed bile duct). More-detailed information on the Danish study can be found in references 7 and 8 .

Data collection took place in the Finnish study through the linkage of union registers (laundry and dry-cleaning workers in the union of chemical and municipal workers) and the payroll data from registered laundry and dry-cleaner employers for the period 1973-1983 with the nationwide hospital discharge register (supplemented with the polyclinic data on spontaneous abortions) and the Finnish register of congenital malformations.

A total of 5700 women had done dry-cleaning or laundry work during the time period in question. They had had 3279 pregnancies, 2307 births, 306 spontaneous abortions, and 606 induced abortions. From every woman only one pregnancy was randomly selected for the analysis in order to avoid nonindependent observations.

Pregnancies which had been terminated as a spontaneous abortion (ICD code 643 and 645) or a congenital malformation (excluding luxation of the hip) were defined as cases. Three age-matched referents for each spontaneous abortion and five matched referents for each malformation were selected according to the nearest available match on age within a \pm 2 -year range from the women who had given birth to a healthy child. To some extent there was a certain overlap between the two reference groups.

Questionnaires were sent to 932 women in the spontaneous abortion group and 185 women in the malformation group to obtain the exposure information. The response rates were $77.2 \%$ in the spontaneous abortion study and $81.1 \%$ in the malformation study.

The following malformations were represented: spina bifida ( 2 cases), malformations of the heart ( 4 cases), malformation of the lip or palate (4 cases), malformation of the digestive tract ( 2 cases), malformation of the urogenital organs (3 cases), malformation of the arms or legs ( 7 cases), other malformations ( 2 cases).

The Finnish data did not include cases defined as stillbirth or low birthweight. Only exposure data from the first trimester were available from the Finnish study. More-detailed information of the Finnish study is given in references 8 and 9 .

\section{Assessment of exposure}

Dry-cleaning shops in the Nordic countries are generally very small and usually employ very few persons.

In the 1960s trichloroethylene was replaced in the dry-cleaning process by tetrachloroethylene, which is now in use in most dry-cleaning plants. However, in recent years, fluorocarbon-113 has been increasingly used.

No continuous monitoring of the exposure takes place in dry-cleaning plants, but several of the work inspectorate's measurements have shown values above the occupational exposure limit, which is now $30 \mathrm{ppm}$ for tetrachloroethylene in Denmark $(20 \mathrm{ppm}$ in Sweden). The highest concentrations are often found around the dry-cleaning machines, especially during the filling or cleaning of equipment.

Exposure assessment had to be based mainly upon anamnestic information. The women's exposure during the first trimester or later in pregnancy was recorded from the women by means of questionnaires or interviews. Some exposure information was also obtained from the employers, eg, the type of production, use of perchloroethylene, etc. Classification was done in Sweden, Denmark, and Norway by an industrial hygienist who had no access to the pregnancy data. For the Finnish data set the exposure was assessed by the researchers according to the reported work history and exposure frequency.

The women were grouped into an unexposed group, a low-exposure group (women working in workplaces with dry-cleaning without being in the high-exposure group), and a high-exposure group (women who actually did dry-cleaning or spot removal at least $1 \mathrm{~h} / \mathrm{d}$ ).

\section{Assessment of pregnancy outcome}

For the sake of comparison and to avoid selection bias in the definition of the case group, all the data on births, spontaneous abortions, birthweights, and congenital malformations have been taken from national computerized registers. Data on births are without doubt complete, but the ascertainment of spontaneous abortions and congenital malformations is not without problems, and the quality of these data probably differ from country to country. Therefore we excluded minor malformations for which we know recording varies from hospital to hospital. The quality of information on malformation is probably better in Finland and Sweden because of their specific research registers in this field. In Denmark and Norway specific birth registers have been used, and in Denmark also the standard hospital register. In all the countries practically all births take place in hospitals, and the same is true for medically treated abortions. Very early, unrecognized abortions are naturally missing from this study.

Medically induced abortions have not been included in the study. However, in a comparison of women with similar socioeconomic status, the frequency and timing of the induced abortions will most likely be similar in the compared groups (10).

Conditional logistic regression analysis was used for the matched data from Norway, Sweden, and Finland. The Danish data were analyzed with the unconditional logistic regression model. When the results from the different countries were combined, each measure of association was weighted according to the inverse variance of the odds ratio, and a combined variance estimate was used in calculating the confidence limits around the odds ratio (11). 
Table 3. Relative risk for all types of reproductive failure (including spontaneous abortion) according to exposure in the first trimester. (OR= odds ratio, $95 \% \mathrm{Cl}=95 \%$ confidence interval)

\begin{tabular}{|c|c|c|c|c|}
\hline Country ${ }^{a}$ & $\begin{array}{l}\text { Cases } \\
\text { (N) }\end{array}$ & $\begin{array}{l}\text { Refer- } \\
\text { ents } \\
\text { (N) }\end{array}$ & $\mathrm{OR}^{b}$ & $95 \% \mathrm{Cl}$ \\
\hline \multicolumn{5}{|l|}{ Sweden } \\
\hline $\begin{array}{l}\text { No exposure } \\
\text { Low exposure } \\
\text { High exposure }\end{array}$ & $\begin{array}{r}18 \\
28 \\
1\end{array}$ & $\begin{array}{r}31 \\
45 \\
3\end{array}$ & $\begin{array}{l}1.0 \\
1.21 \\
0.83\end{array}$ & $\begin{array}{l}0.50-2.91 \\
0.07-9.50\end{array}$ \\
\hline \multicolumn{5}{|l|}{ Denmark } \\
\hline $\begin{array}{l}\text { No exposure } \\
\text { Low exposure } \\
\text { High exposure }\end{array}$ & $\frac{10}{2}$ & $\begin{array}{r}112 \\
13 \\
6\end{array}$ & $\begin{array}{l}1.0 \\
0.00 \\
3.92\end{array}$ & 0.69-22.4 \\
\hline \multicolumn{5}{|l|}{ Finland } \\
\hline $\begin{array}{l}\text { No exposure } \\
\text { Low exposure } \\
\text { High exposure }\end{array}$ & $\begin{array}{r}103 \\
33 \\
6\end{array}$ & $\begin{array}{r}251 \\
65 \\
4\end{array}$ & $\begin{array}{l}1.0 \\
1.23 \\
3.59\end{array}$ & $\begin{array}{l}0.75-2.01 \\
0.97-13.4\end{array}$ \\
\hline \multicolumn{5}{|l|}{$\begin{array}{l}\text { All three countries } \\
\text { combined }\end{array}$} \\
\hline $\begin{array}{l}\text { Low exposure } \\
\text { High exposure }\end{array}$ & . & . & $\begin{array}{l}1.23 \\
2.95\end{array}$ & $\begin{array}{l}0.81-1.87 \\
1.14-7.65 \\
\end{array}$ \\
\hline \multicolumn{5}{|c|}{$\begin{array}{l}\text { Low exposure = work in dry cleaning but not in the high- } \\
\text { exposure group, high exposure = dry-cleaning work and spot } \\
\text { removal at least } 1 \mathrm{~h} / \mathrm{d} \text {. } \\
\text { b OR adjusted for parity, smoking, and drinking habits (two cat- } \\
\text { egories for all adjustments); Danish data only adjusted for } \\
\text { parity and smoking habits (two categories for both adjust- } \\
\text { ments). }\end{array}$} \\
\hline
\end{tabular}

Table 4. Relative risk for spontaneous abortion according to exposure in the first trimester. (OR $=$ odds ratio, $95 \%$ $\mathrm{Cl}=95 \%$ confidence interval)

\begin{tabular}{lrrrc}
\hline Country & $\begin{array}{c}\text { Cases } \\
\text { (N) }\end{array}$ & $\begin{array}{c}\text { Refer- } \\
\text { ents } \\
(\mathrm{N})\end{array}$ & OR $^{\mathrm{b}}$ & $95 \% \mathrm{Cl}$ \\
\hline Sweden & & & & \\
$\quad$ No exposure & 14 & 24 & 1.0 &. \\
$\quad$ Low exposure & 16 & 26 & 1.15 & $0.43-3.09$ \\
$\quad$ High exposure & 1 & 3 & 0.82 & $0.07-9.86$ \\
Denmark & & & & \\
$\quad$ No exposure & 9 & 100 & 1.0 &. \\
$\quad$ Low exposure & - & 13 & 0.00 &. \\
$\quad$ High exposure & 1 & 6 & 2.52 & $0.26-24.1$ \\
Finland & & & & \\
$\quad$ No exposure & 84 & 204 & 1.0 &. \\
$\quad$ Low exposure & 28 & 57 & 1.18 & $0.71-1.97$ \\
$\quad$ High exposure & 6 & 3 & 4.53 & $1.11-18.5$ \\
\hline
\end{tabular}

\section{All three countries}

combined

\begin{tabular}{lllll} 
Low exposure & $\cdot$ & $\cdot$ & 1.17 & $0.74-1.85$ \\
High exposure & $\cdot$ & $\cdot$ & 2.88 & $0.98-8.44$ \\
\hline
\end{tabular}

a Low exposure $=$ work in dry cleaning but not in the highexposure group, high exposure $=$ dry-cleaning work and spot removal at least $1 \mathrm{~h} / \mathrm{d}$.

b Same confounder adjustment as in table 3.

Table 5. Relative risk for congenital malformation, still birth, and low birthweight $(<1500 \mathrm{~g})$ combined according to exposure in various trimesters of pregnancy. (OR= odds ratio, $95 \% \mathrm{Cl}=95 \%$ confidence interval)

\begin{tabular}{|c|c|c|c|c|}
\hline Countrya & $\begin{array}{l}\text { Cases } \\
(\mathrm{N})\end{array}$ & $\begin{array}{l}\text { Referents } \\
\text { (N) }\end{array}$ & OR & $95 \% \mathrm{Cl}$ \\
\hline \multicolumn{5}{|c|}{ Sweden, first trimester } \\
\hline $\begin{array}{l}\text { No exposure } \\
\text { Low exposure } \\
\text { High exposure }\end{array}$ & $\begin{array}{r}4 \\
10 \\
2\end{array}$ & $\begin{array}{r}7 \\
12 \\
7\end{array}$ & $\begin{array}{l}1.0 \\
2.23 \\
0.48\end{array}$ & $\begin{array}{l}0.47-10.52 \\
0.09-2.63\end{array}$ \\
\hline \multicolumn{5}{|c|}{ Finland, first trimester } \\
\hline $\begin{array}{l}\text { No exposure } \\
\text { Low exposure } \\
\text { High exposure }\end{array}$ & $\begin{array}{r}19 \\
5 \\
-\end{array}$ & $\begin{array}{r}71 \\
21 \\
1\end{array}$ & $\begin{array}{l}1.0 \\
0.81 \\
\cdots\end{array}$ & $0.27-2.43$ \\
\hline $\begin{array}{c}\text { Sweden, second-t } \\
\text { No exposure } \\
\text { Low exposure } \\
\text { High exposure }\end{array}$ & $\begin{array}{r}4 \\
10 \\
2\end{array}$ & $\begin{array}{r}7 \\
13 \\
5\end{array}$ & $\begin{array}{l}1.0 \\
1.46 \\
0.66\end{array}$ & $\begin{array}{c}0.34-6.36 \\
0.10-4.40\end{array}$ \\
\hline \multicolumn{5}{|c|}{ Sweden, all trimesters ${ }^{b}$} \\
\hline $\begin{array}{l}\text { No exposure } \\
\text { Low exposure } \\
\text { High exposure }\end{array}$ & $\begin{array}{l}6 \\
9 \\
1\end{array}$ & $\begin{array}{r}10 \\
11 \\
5\end{array}$ & $\begin{array}{l}1.0 \\
1.72 \\
0.31\end{array}$ & $\begin{array}{c}0.42-7.15 \\
0.31-3.10\end{array}$ \\
\hline \multicolumn{5}{|c|}{ Norway, all trimesters ${ }^{b}$} \\
\hline $\begin{array}{l}\text { No exposure } \\
\text { Low exposure } \\
\text { High exposure }\end{array}$ & $\frac{13}{1}$ & $\begin{array}{r}19 \\
5 \\
4\end{array}$ & $\begin{array}{l}1.0 \\
0.43\end{array}$ & $\begin{array}{c}\therefore \\
0.04-4.61\end{array}$ \\
\hline \multicolumn{5}{|c|}{ Denmark, all trimesters ${ }^{b}$} \\
\hline $\begin{array}{l}\text { No exposure } \\
\text { Low exposure } \\
\text { High exposure }\end{array}$ & $\frac{1}{1}$ & $\begin{array}{r}117 \\
5 \\
9 \\
\end{array}$ & $\begin{array}{c}1.0 \\
\cdots \\
15.95 \\
\end{array}$ & $\begin{array}{c}\therefore \\
0.74-345.34 \\
\end{array}$ \\
\hline \multicolumn{5}{|c|}{$\begin{array}{l}\text { All three countries combined, } \\
\text { all trimesters }{ }^{b}\end{array}$} \\
\hline $\begin{array}{l}\text { Low exposure } \\
\text { High exposure }\end{array}$ & $\dot{-}$ & $\dot{r}$ & $\begin{array}{l}1.72 \\
0.87\end{array}$ & $\begin{array}{l}0.40-7.12 \\
0.20-3.69\end{array}$ \\
\hline
\end{tabular}

a In the Swedish, Norwegian, and Danish data "high exposure" equals dry cleaning at least $2 \mathrm{~h} /$ week or cloth ironing/pressing more than $20 \mathrm{~h} /$ week or in charge of cleaning or filling the cleaning equipment. The "low exposure" category includes all others working in dry cleaning. Finnish data are coded as in tables 3 and 4.

b Exposure throughout pregnancy. 


\section{Results}

In table 3 all the reproductive failures have been included. The Swedish data showed odds ratios that were very close to unity. The Danish and Finnish results were similar for the high-exposure group, showing an odds ratio of 3 to 4 . In the combined analysis the finding for the high-exposure group was statistically significant.

Similar results appear in table 4 for spontaneous abortions. The highly exposed group of the Finnish data set had an odds ratio that was elevated statistically significantly for spontaneous abortions. This finding was moderately supported by the Danish data.

In table 5 only reproductive failures in relation to births are presented. Almost all of the results pointed towards no statistical association, and none of the results - including the odds ratio of the meta-analysis - were statistically significant at the $5 \%$ level. The exposure status for all trimesters is given only for those women who kept the same exposure status throughout pregnancy.

\section{Discussion}

In spite of attempts to follow a common Nordic study protocol, practical problems such as possible ways of identifying dry-cleaning plants, different coverage and regulations in the use of medical registers, etc, caused a number of differences in the study design. Possible differences in diagnostic procedures should also be taken into consideration. For this reason the data were not pooled and analyzed as one data set. Less ambitious techniques of pooling results rather than data have been used, and the overall estimate should be read with caution. The amount of information obtained by a combined effort from four countries is still rather limited.

The Finnish and the Danish results pointed towards an association between dry-cleaning work and spontaneous abortion for highly exposed women, but most of the other results were more in line with the null hypothesis. This result could be due to random variation, but it may also reflect different exposure settings or differences in the jobs performed by men and women in the different countries.

This study did not cover all dry-cleaning plants. Some plants could not be located (maybe 10-30\%), and some plant owners refused to participate. Thus it is possible that the participating plants may have had better work conditions than nonparticipating plants. Especially in Sweden the coverage was low (see table 1), and this low level of coverage could partly explain the difference in the findings. The Swedish researchers therefore carried out a complementary study, but it did not indicate a higher risk among workers in the nonparticipating plants (7).

In the Danish, Finnish, and Swedish studies the women were questioned about past exposure. The use of this procedure could have led the cases to exaggerate their exposure during pregnancy and thus lead to bias by inaccurate information. However, in all the studies, exposure data were also collected from the employers. When this exposure information was used, the results resembled the present ones.

Controlling for confounding due to life-style factors was only possible to a limited extent for statistical reasons.

In a data set of very moderate size there is clearly a limit to the number of variables which can be taken into consideration in the analysis. However, substantial confounding due to smoking and drinking habits was unlikely, since all the women had similar work conditions and a similar socioeconomic status. Our data do not indicate that the exposed women differed from the unexposed ones in essential life-style factors.

Exposure during pregnancy may cause very specific outcomes, such as specific types of spontaneous abortion or specific types of malformation. The size of the study did not permit very strict case definitions, and spontaneous abortions are not subclassified in the registers. Very specific cause-effect relationships will therefore not show up in a study such as ours. However, nothing in the present data pointed towards specific malformations being related to dry cleaning. However, for further evaluation of a more specific malformation, a larger study is needed.

It was not possible to classify exposure data in exactly the same manner in table 5, but none of the results indicated a link between dry-cleaning work and the prevalence of malformation as such.

\section{Acknowledgments}

The Nordic collaboration received financial support from the Nordic Council of Ministers. The study in Sweden was financed by the Swedish Work Environment Fund. In Norway financial support was received from the Royal Ministry of Local Government and Labour and the A/S Borregaard Research Fund. In Denmark the Medical Research Fund (12-5823) and Helsefondet (H11/17-85) supported the study. In Finland a grant was given by the Finnish Work Environment Fund.

\section{References}

1. International Agency for Research on Cancer. Overall evaluations of carcinogenicity: an updating of IARC monographs volumes 1 to 42. Lyon: International Agency for Research on Cancer, 1988:355-7. (IARC monographs; suppl 7.)

2. Schwetz BA, Leong BKJ, Gehring PJ. The effect of maternally inhaled trichloroethylene, perchloroethylene, methylchloroform and methylene chloride in embryonal and fetal development in mice and rats. Toxicol Appl Pharmacol 1975;32:941-9.

3. Elovaara E, Hemminki K, Vainio H. Effects of methylenechloride trichloroethane, trichloroethylene, 
tetrachloroethylene and toluene on development of chick embryos. Toxicology 1979;12:111-9.

4. Hemminki K, Franssila E, Vainio H. Spontaneous abortions among female chemical workers in Finland. Int Arch Occup Environ Health 1980;45:123-6.

5. Bosco MG, Figá-Talamanca I, Salerno S. Health and reproductive status of female workers in dry cleaning shops. Int Arch Occup Environ Health 1987;59:295301.

6. Lindbohm M-L, Hemminki K, Kyyrönen P. Parental occupational exposure and spontaneous abortions in Finland. Am J Epidemiol 1984;120:370-8.

7. Ahlborg G. Pregnancy outcome among women working in laundries and dry cleaning shops using tetrachloroethylene. Am J Ind Med (in press).
8. Kolstad H, Brandt L, Rasmussen K. Klorerede opløsningsmidler og fosterskader [Chlorinated solvents and the risk of fetal damage]. Ugeskr Laeger (in press).

9. Kyyrönen $\mathrm{P}$, Taskinen $\mathrm{H}$, Lindbohm M-L, et al. Spontaneous abortions and congenital malformations among women exposed to tetrachloroethylene in dry cleaning. J Epidemiol Community Health 1989;43:346-51.

10. Olsen J. Calculating risk ratios for spontaneous abortions: the problem of induced abortions. Int J Epidemiol 1984;13:347-50.

11. Greenland S. Quantitative methods in the review of epidemiologic literature. Epidemiol Rev 1987;9:1-30.

Received for publication: 6 July 1989 